\title{
Antimicrobial Activity of Terminalia catappa L. Leaf Extracts against Some Clinically Important Pathogenic Microbial Strains
}

\author{
Sumitra Chanda*, Kalpna Rakholiya, Rathish Nair \\ ${ }^{1}$ Phytochemical, Pharmacological and Microbiological Laboratory, Department of Biosciences, \\ Saurashtra University, Rajkot, India \\ E-mail: "svchanda@gmail.com
}

Received July 27, 2011; revised September 2, 2011; accepted September 14, 2011

\begin{abstract}
Objective: The present study was undertaken to evaluate in-vitro antimicrobial activity of methanol, acetone and N, N-dimethylformamide extracts from leaf of Terminalia catappa L. (Combretaceae). Methods: In vitro antimicrobial activity of all the extracts was done by agar disc diffusion assay. 91 clinically important strains were used for the study, which were both clinical isolates as well as identified strains. Piperacillin and gentamicin were used as standards for antibacterial assay, while nystatin and flucanazole were used as standards for antifungal assay. Antimicrobial activity was determined by measurement of inhibition zone around each paper disc. For each extract three replicate trials were conducted against each organism. Results: The antibacterial activity was more pronounced against bacteria than fungal strains. The Gram positive bacteria were more susceptible than Gram negative bacteria. The methanol extract showed best antibacterial activity. T. catappa leaf extracts showed better antibacterial activity than commercially used antibiotics. Conclusion: Demonstration of antimicrobial activity of $T$. catappa provides the scientific basis for the use of this plant in the traditional treatment of diseases and may help to discover new chemical classes of antibiotic substances that could serve as selective agents for infectious disease chemotherapy and control. This investigation has opened up the possibility of the use of this plant in drug development for human consumption possibly for the treatment of various infections caused by microbes.
\end{abstract}

Keywords: Terminalia catappa, Antibacterial Activity, Antifungal Activity, Clinical Strains, Organic Solvents

\section{Introduction}

Traditional medicine has been practiced for many centuries in many parts of the world, including India especially in rural areas due to availability and low cost. Nature has provided a source of medicinal agents for thousands of years and an impressive number of modern drugs have been isolated from natural sources, many based on their use in traditional medicine [1]. There has been an increasing incidence of multiple resistances in human pathogenic microorganisms, largely due to the indiscriminate use of commercial antimicrobial drugs commonly employed in the treatment of infectious diseases [2]. The development of bacterial resistance to presently available antibiotics has necessitated the search for new antibacterial agents. Numerous studies have been conducted with the extracts of various plants, screening antimicrobial activity as well as for the discovery of new antimicrobial compounds [3-6]. The efforts of scientists in establishing plants with promising antimicrobial property is yielding fruitful results as a number of plants with high antimicrobial property have been elucidated [7-13].

Terminalia catappa L. belongs to the family Combretaceae. T. catappa is used primarily as an ornamental, shade, and salt-tolerant street tree, but the leaves provide food for the Tasar silkworm, and the seeds are edible like almonds with similar oils. On the Malay peninsular and through the Canary islands this tree is known as the tropical almond. T. catappa has been claimed to have therapeutic effects for liver related diseases [14]. In Java, it is attributed with cholagogue action. In India, it is used as cardiac stimulant. Its leaves are widely used as a folk 
medicine in Southeast Asia for the treatment of dermatosis and hepatitis [15]. More and more pharmacological studies have reported that the extract of T. catappa leaves and fruits have anticancer, antioxidant, anti-HIV reverse transcriptase, anti-inflammatory, antidiabetic effects and hepatoprotective activities [16-19] but the effective components and related mechanisms remain unknown.

In the present work, antimicrobial activity of $T$. $\mathrm{ca}$ tappa leaf extracts were investigated against an array of clinically isolated as well as standard microbial cultures.

\section{Material and Methods}

\subsection{Plant Material}

The leaves of T. catappa were collected in February, 2005 from Rajkot in the State of Gujarat Western India and identified by comparison with specimens PSN 291 available at the Herbarium of the Department of Biosciences, Saurashtra University, Rajkot, Gujarat, India.

\subsection{Extraction}

The leaves of T. catappa were air dried and then powdered in a homogenizer and $10 \mathrm{~g}$ was used for different solvent extraction N, N-dimethylformamide (DMF), acetone and methanol, the sample was extracted in solvent kept on a rotary shaker overnight, and then the filtrate was collected and centrifuged at $5000 \mathrm{rpm}$. The solvent was then evaporated to dryness under reduced pressure and the extracted compound left was used for the antimicrobial assay. The percentage yield of N, N-dimethylformamide (DMF), acetone and methanol extracts were 20.92, 4.96 and 14.48 respectively.

\subsection{Microorganisms Studied}

91 clinically important microbial strains which included 20 Gram positive, 55 Gram negative and 16 fungal strains were studied for the antimicrobial activity. These strains included both clinical isolates as well as identified strains. The identified strains were obtained from National Chemical Laboratory (NCL), Pune, India and clinical isolates were obtained from Spandan Diagnostic and Microcare Diagnostic Laboratory, Rajkot, Gujarat, India (Tables 1-5). The bacteria were grown in the nutrient broth and maintained on nutrient agar slants at $4^{\circ} \mathrm{C}$ while fungal strains were grown in Sabouraud dextrose broth and maintained on MGYP slants for yeast and potato dextrose agar slants for mould at $4^{\circ} \mathrm{C}$.

Table 1. Antibacterial activity of Terminalia catappa leaf extracts against some Gram positive bacteria.

\begin{tabular}{|c|c|c|c|c|c|c|}
\hline \multirow{2}{*}{$\begin{array}{l}\text { Sr. } \\
\text { No. }\end{array}$} & \multirow{2}{*}{$\begin{array}{c}\text { Strain } \\
\text { (Location of collection) }\end{array}$} & \multicolumn{5}{|c|}{ Zone of inhibition $(\mathrm{mm})^{\mathrm{a}}$} \\
\hline & & TME & TAE & TDE & G & Pc \\
\hline 1 & Staph-1 (Sputum) & $14.67 \pm 0.33$ & $9.66 \pm 0.33$ & $10 \pm 0.58$ & - & - \\
\hline 2 & S. aureus (Pus) & $14 \pm 0$ & $11 \pm 0.58$ & $9 \pm 1.15$ & $18.67 \pm 0.33$ & $17.33 \pm 0.33$ \\
\hline 3 & S. aureus (Urine) & $13 \pm 0.58$ & $9 \pm 0.58$ & $8 \pm 0.58$ & - & - \\
\hline 4 & S. aureus (Pus) & $16 \pm 0.58$ & $8 \pm 0.58$ & $14 \pm 0.58$ & - & - \\
\hline 5 & Staph-2 (Pus) & - & - & - & - & - \\
\hline 6 & S. aureus (Sputum) & - & - & - & - & - \\
\hline 7 & S. aureus (Tracheal) & $15 \pm 0.58$ & $10 \pm 0.58$ & $9.67 \pm 0.33$ & - & - \\
\hline 8 & S. aureus (Tracheal) & $15 \pm 0.58$ & $12 \pm 0.59$ & $13 \pm 0.58$ & - & - \\
\hline 9 & Staph-3 (Sputum) & $14.33 \pm 0.66$ & $12.33 \pm 0.88$ & $10 \pm 1.73$ & $14.67 \pm 0.33$ & - \\
\hline 10 & S. aureus (Ear swab) & $16.67 \pm 1.53$ & $14 \pm 2.89$ & $10 \pm 1.73$ & - & - \\
\hline 11 & S. aureus (Sputum) & $18.67 \pm 0.33$ & $14 \pm 0.58$ & $13 \pm 0.58$ & $20.67 \pm 0.33$ & - \\
\hline 12 & S. aureus (Pus) & - & - & - & - & - \\
\hline 13 & S. aureus (Pus) & - & - & - & $10.33 \pm 0.33$ & - \\
\hline 14 & S. aureus (ATCC25923) & $14.5 \pm 0.28$ & $8.5 \pm 0.86$ & $10 \pm 1.73$ & - & - \\
\hline 15 & S. epidemidies (ATCC12228) & $11 \pm 0.58$ & - & - & - & - \\
\hline 16 & S. subflava (NCIM2178) & $19 \pm 0.58$ & $13.5 \pm 1.44$ & $11.5 \pm 0.28$ & - & $20.17 \pm 0.44$ \\
\hline 17 & B. cereus (ATCC11778) & $11.5 \pm 0.28$ & $9.5 \pm 0.28$ & $11 \pm 0.58$ & $20.17 \pm 0.16$ & $18.83 \pm 0.16$ \\
\hline 18 & B. subtilis (ATCC6633) & $9 \pm 1.15$ & $8.5 \pm 0.86$ & - & $18.33 \pm 0.33$ & $17.83 \pm 0.93$ \\
\hline 19 & B. mega (ATCC9885) & - & - & - & - & - \\
\hline 20 & M. flavus (ATCC10240) & $14 \pm 0.58$ & $8.5 \pm 0.86$ & $15 \pm 1.15$ & $27.67 \pm 0.33$ & $12.67 \pm 0.33$ \\
\hline
\end{tabular}

${ }^{\mathrm{a}}$ Values are Mean $\pm \mathrm{SEM}, \mathrm{n}=3$, zone includes disc diameter $7 \mathrm{~mm}$; G-Gentamicin $(10 \mu \mathrm{g} /$ disc $)$; Pc-Piperacillin (100 $\mu \mathrm{g} /$ disc $)$; TME-Methanol extract; TAE-Acetone extract; TDE-N, N-dimethylformamide (DMF) extract; “-” means no activity; Staph—Staphylococcus species. 
Table 2. Antibacterial activity of Terminalia catappa leaf extracts against some Pseudomonas species.

\begin{tabular}{|c|c|c|c|c|c|c|}
\hline \multirow{2}{*}{$\begin{array}{l}\text { Sr. } \\
\text { No. }\end{array}$} & \multirow{2}{*}{$\begin{array}{c}\text { Strain } \\
\text { (Location of collection) }\end{array}$} & \multicolumn{5}{|c|}{ Zone of inhibition $(\mathbf{m m})^{a}$} \\
\hline & & TME & TAE & TDE & G & Pc \\
\hline 1 & Ps. aeruginosa (ATCC27853) & - & - & - & $17 \pm 1.15$ & $12.33 \pm 0.66$ \\
\hline 2 & Ps. aeruginosa (Sputum) & - & - & - & $16.67 \pm 0.67$ & - \\
\hline 3 & Ps. aeruginosa (Pus) & - & - & - & $19.67 \pm 0.33$ & - \\
\hline 4 & Ps. fluorescence (Tracheal) & $8.67 \pm 0.33$ & - & $12.67 \pm 1.44$ & - & - \\
\hline 5 & Ps. fluorescence (Pus) & $13.67 \pm 3.18$ & $8 \pm 0.58$ & - & - & - \\
\hline 6 & Ps. fluorescence (Urine) & - & - & - & - & - \\
\hline 7 & Ps. testosterone (NCIM5098) & - & - & - & $22.33 \pm 0.66$ & - \\
\hline 8 & Ps. pseudoalcaligenes (ATCC17440) & $15.5 \pm 0.28$ & $12.5 \pm 0.86$ & $14.5 \pm 028$ & $19.33 \pm 0.6$ & - \\
\hline 9 & Pseudo-1 (Sputum) & $11 \pm 2.31$ & $13 \pm 0.58$ & $11.67 \pm 0.33$ & $14 \pm 0.58$ & - \\
\hline 10 & Pseudo-2 (Pus) & $13.67 \pm 3.18$ & $8 \pm 0.58$ & - & - & - \\
\hline 11 & Pseudo-3 (Urine) & $14.67 \pm 1.45$ & $16 \pm 0.58$ & $14.67 \pm 0.33$ & - & - \\
\hline 12 & Pseudo-4 (Pus) & $14 \pm 0.58$ & $10.6 \pm 2.34$ & $9.33 \pm 1.23$ & - & - \\
\hline 13 & Pseudo-5 (Tracheal) & - & - & - & - & - \\
\hline 14 & Pseudo-6 (Wound swab) & - & - & - & - & - \\
\hline 15 & Pseudo-7 (Pus) & $16 \pm 0.56$ & $10 \pm 0.58$ & $12 \pm 1.15$ & - & - \\
\hline 16 & Pseudo-8 (Tracheal secretion) & $14 \pm 1.15$ & $9 \pm 1.15$ & $9 \pm 1.15$ & - & - \\
\hline 17 & Pseudo-9 (Pus) & $11.67 \pm 0.88$ & $9.33 \pm 1.20$ & - & - & - \\
\hline 18 & Pseudo-10 (Sputum) & $17 \pm 0.58$ & $12 \pm 0.33$ & $13.67 \pm 0.88$ & - & - \\
\hline 19 & Pseudo-11 (Sputum) & $18.33 \pm 0.33$ & $16.33 \pm 1.45$ & $13 \pm 0.58$ & $20 \pm 0.58$ & - \\
\hline
\end{tabular}

${ }^{\mathrm{a}}$ Values are Mean $\pm \mathrm{SEM}, \mathrm{n}=3$, zone includes disc diameter $7 \mathrm{~mm}$; G-Gentamicin $(10 \mu \mathrm{g} /$ disc $)$; Pc—Piperacillin $(100 \mu \mathrm{g} /$ disc $)$; TME—Methanol extract; TAE-Acetone extract; TDE-N, N-dimethylformamide (DMF) extract; “-" means no activity; Pseudo-Pseudomonas species.

Table 3. Antibacterial activity of Terminalia catappa leaf extracts against some $E$. coli isolates.

\begin{tabular}{|c|c|c|c|c|c|c|}
\hline \multirow{2}{*}{$\begin{array}{l}\text { Sr. } \\
\text { No. }\end{array}$} & \multirow{2}{*}{$\begin{array}{c}\text { Strain } \\
\text { (Location of collection) }\end{array}$} & \multicolumn{5}{|c|}{ Zone of inhibition (mm) ${ }^{a}$} \\
\hline & & TME & TAE & TDE & G & Pc \\
\hline 1 & E. coli (Pus) & $10 \pm 1.53$ & $8.66 \pm 0.88$ & $7.66 \pm 0.33$ & - & - \\
\hline 2 & E. coli (Urine) & $12.33 \pm 2.73$ & $9.66 \pm 1.45$ & - & - & - \\
\hline 3 & E. coli (Urine) & $16 \pm 0.58$ & $12.33 \pm 0.88$ & $11.67 \pm 0.33$ & - & - \\
\hline 4 & E. coli (Urine) & $15 \pm 0.88$ & $10 \pm 0.33$ & $13 \pm 0.58$ & - & - \\
\hline 5 & E. coli (Urine) & $15 \pm 0.88$ & $11 \pm 0.58$ & $14 \pm 0.33$ & - & - \\
\hline 6 & E. coli (Pus) & $10 \pm 0.58$ & $14 \pm 0.88$ & $13 \pm 1.15$ & - & - \\
\hline 7 & E. coli (Urine) & $14.33 \pm 1.20$ & $12 \pm 0.58$ & $14 \pm 1.15$ & - & - \\
\hline 8 & E. coli (Stool) & $15.67 \pm 0.33$ & $10.67 \pm 0.33$ & $13 \pm 0.58$ & $21 \pm 0.58$ & - \\
\hline 9 & E. coli (Pus) & $12 \pm 0.58$ & $11.33 \pm 0.88$ & $14.67 \pm 0.33$ & - & - \\
\hline 10 & E. coli (Urine) & $14.33 \pm 0.33$ & $10.67 \pm 0.33$ & $14 \pm 0.58$ & $18.67 \pm 0.33$ & - \\
\hline 11 & E. coli (Pus) & $12.67 \pm 0.66$ & $11.67 \pm 0.33$ & $11.33 \pm 0.66$ & - & - \\
\hline 12 & E. coli (Urine) & $15.33 \pm 0.88$ & $12.67 \pm 0.33$ & $14 \pm 0.58$ & $20.33 \pm 0.33$ & - \\
\hline 13 & E. coli (Vaginal swab) & $13.5 \pm 0.28$ & - & $12.67 \pm 0.33$ & - & - \\
\hline 14 & E. coli (Urine) & - & - & - & - & - \\
\hline 15 & E. coli (Blood) & $14.5 \pm 0.28$ & - & - & - & - \\
\hline 16 & E. coli (ATCC25922) & $14 \pm 0.58$ & $10 \pm 1.73$ & - & $17.83 \pm 0.16$ & $14.5 \pm 0.50$ \\
\hline
\end{tabular}

${ }^{\mathrm{a}}$ Values are Mean $\pm \mathrm{SEM}, \mathrm{n}=3$, zone includes disc diameter $7 \mathrm{~mm}$; G-Gentamicin $(10 \mu \mathrm{g} / \mathrm{disc})$; Pc-Piperacillin (100 $\left.\mu \mathrm{g} / \mathrm{disc}\right)$; TME-Methanol extract; TAE-Acetone extract; TDE-N, N-dimethylformamide (DMF) extract; “-” means no activity. 
Table 4. Antibacterial activity of Terminalia catappa leaf extracts against some Gram negative bacteria.

\begin{tabular}{|c|c|c|c|c|c|c|}
\hline \multirow{2}{*}{$\begin{array}{l}\text { Sr. } \\
\text { No. }\end{array}$} & \multirow{2}{*}{$\begin{array}{c}\text { Strain } \\
\text { (Location of collection) }\end{array}$} & \multicolumn{5}{|c|}{ Zone of inhibition $(\mathrm{mm})^{\mathrm{a}}$} \\
\hline & & TME & TAE & TDE & G & Pc \\
\hline 1 & Ent-1 (Tracheal) & $8.33 \pm 0.88$ & - & - & - & - \\
\hline 2 & Ent-2 (Tracheal) & $11 \pm 1.15$ & - & $8 \pm 0.58$ & $19.67 \pm 0.88$ & - \\
\hline 3 & E. aerogenes (ATCC 13048) & - & - & - & - & - \\
\hline 4 & Kleb-1 (Urine) & $13.67 \pm 0.88$ & $11 \pm 0.58$ & $11 \pm 0.58$ & $22 \pm 0.58$ & - \\
\hline 5 & Kleb-1 (Sputum) & $14 \pm 0.58$ & $10.33 \pm 0.33$ & $10 \pm 0.58$ & - & - \\
\hline 6 & K. aerogenes (Pus) & $8 \pm 0.58$ & - & $8.67 \pm 0.88$ & - & - \\
\hline 7 & Kleb-2 (Urine) & $14 \pm 0.58$ & $12.33 \pm 0.33$ & $14.67 \pm 0.33$ & - & - \\
\hline 8 & K. aerogenes (Urine) & $13.67 \pm 0.33$ & $10.67 \pm 0.33$ & $13.33 \pm 0.33$ & - & - \\
\hline 9 & K. pneumoniae (NCIM2719) & - & - & - & - & $24.67 \pm 0.33$ \\
\hline 10 & P. mirabilis (Wound swab) & $18 \pm 1.20$ & $10.33 \pm 0.33$ & $12.67 \pm 0.33$ & - & $14 \pm 0.58$ \\
\hline 11 & Prot-1 (Pus) & $14.67 \pm 0.33$ & $10 \pm 0.58$ & $13.33 \pm 0.33$ & - & - \\
\hline 12 & P. mirabilis (NCIM2241) & - & - & - & $18.67 \pm 0.33$ & - \\
\hline 13 & P. vulgaris (NCTC8313) & $14.5 \pm 0.28$ & - & - & $18 \pm 1.00$ & - \\
\hline 14 & P. morganii (NCIM2040) & - & - & - & - & - \\
\hline 15 & P. rettgeri (Pus) & $16.33 \pm 0.88$ & $10.67 \pm 0.33$ & $11.67 \pm 0.33$ & - & - \\
\hline 16 & Citro-1 (Pus) & $12 \pm 0.58$ & $9 \pm 0.58$ & $10 \pm 1.16$ & - & - \\
\hline 17 & C. freundii (Pus) & - & - & - & $12.33 \pm 0.33$ & - \\
\hline 18 & C. freundii (ATCC10787) & - & - & - & - & - \\
\hline 19 & A. fecalis (ATCC8750) & - & - & - & $18.33 \pm 0.66$ & - \\
\hline 20 & S. typhimurium (ATCC23564) & $12 \pm 0.58$ & $8.5 \pm 0.86$ & $10.5 \pm 0.86$ & $18.5 \pm 0.28$ & - \\
\hline
\end{tabular}

${ }^{a}$ Values are Mean \pm SEM, $\mathrm{n}=3$, zone includes disc diameter $7 \mathrm{~mm}$; G-Gentamicin $(10 \mu \mathrm{g} / \mathrm{disc}) ; \mathrm{Pc}-$ Piperacillin $(100 \mu \mathrm{g} /$ disc $)$; TME—Methanol extract; TAE-Acetone extract; TDE-N, N-dimethylformamide (DMF) extract; “-” means no activity; Ent—Enterobacter species; Kleb—Klebsiella species; Citro-Citrobacter species; Prot-Proteus species.

Table 5. Antifungal activity of Terminalia catappa leaf extracts.

\begin{tabular}{|c|c|c|c|c|c|c|}
\hline \multirow{2}{*}{$\begin{array}{l}\text { Sr. } \\
\text { No. }\end{array}$} & \multirow{2}{*}{$\begin{array}{c}\text { Fungus } \\
\text { (Location of collection) }\end{array}$} & \multicolumn{5}{|c|}{ Zone of inhibition $(\mathrm{mm})^{\mathrm{a}}$} \\
\hline & & TME & TAE & TDE & $\mathbf{F u}$ & Ns \\
\hline 1 & Candida spp. (Sputum) & - & - & - & - & $14 \pm 0.58$ \\
\hline 2 & C. albicans (Urine) & - & $7.5 \pm 0.29$ & $10 \pm 1.73$ & - & $11.33 \pm 0.33$ \\
\hline 3 & C. albicans (Sputum) & - & - & - & - & $18 \pm 0.58$ \\
\hline 4 & Candida spp. (Sputum) & - & - & - & - & $14 \pm 0.58$ \\
\hline 5 & Candida spp. (Urine) & - & - & - & - & $10 \pm 0.58$ \\
\hline 6 & C. albicans (ATCC2091) & $8.5 \pm 0.87$ & $8.5 \pm 0.87$ & - & $17.67 \pm 0.33$ & $13 \pm 0.58$ \\
\hline 7 & C. albicans (ATCC18804) & - & - & - & - & $14.33 \pm 0.33$ \\
\hline 8 & C. glabrata (NCIM3448) & - & - & - & $39.67 \pm 0.88$ & $22 \pm 0.58$ \\
\hline 9 & C. tropicalis (ATCC4563) & - & - & - & - & $8.33 \pm 0.33$ \\
\hline 10 & C. apicola (NCIM3367) & $19.33 \pm 0.33$ & $13 \pm 1.15$ & $14.33 \pm 0.33$ & - & $21.33 \pm 0.88$ \\
\hline 11 & C. neoformans (ATCC34664) & - & - & - & $21.33 \pm 0.33$ & $17 \pm 0.58$ \\
\hline 12 & C. luteolus (ATCC32044) & $17.5 \pm 2.60$ & $8.5 \pm 0.86$ & - & $23.66 \pm 0.88$ & $17.66 \pm 0.88$ \\
\hline 13 & T. beigelii (NCIM3404) & $12 \pm 0.58$ & $12 \pm 0.58$ & $7.5 \pm 0.29$ & - & - \\
\hline 14 & A. flavus (NCIM538) & - & - & - & - & - \\
\hline 15 & A. candidus (NCIM883) & - & - & - & - & - \\
\hline 16 & A. niger (ATCC6275) & - & - & - & - & - \\
\hline
\end{tabular}

${ }^{\mathrm{a}}$ Values are Mean $\pm \mathrm{SEM}, \mathrm{n}=3$, zone includes disc diameter $7 \mathrm{~mm}$; Ns-Nystatin (100 units/disc); Fu-Fluconazole (10 $\mu \mathrm{g} /$ disc); TME-Methanol extract; TAE-Acetone extract; TDE—N, N-dimethylformamide (DMF) extract; “-” means no activity; Fu—Fluconazole; Ns-Nystatin. 


\subsection{Antimicrobial Assay}

The N, N-Dimethyl formamide extract (TDE), acetone extract (TAE) and methanol extract (TME) were dissolved in DMSO. The antimicrobial activity was evaluated at a concentration of $250 \mu \mathrm{g} / \mathrm{disc}$. Antimicrobial activity was performed by agar disc diffusion method [20,21]. The bacterial strains were grown in nutrient broth while fungal strains were grown in MGYP (Malt glucose yeast peptone) broth. Mueller Hinton agar No. 2 was the media used to study the antibacterial susceptibility while Sabouraud dextrose agar was used to study the antifungal susceptibility test. The cultures were grown for $24 \mathrm{~h}$, and the turbidity of the culture was maintained according to the $0.5 \mathrm{MacF}$ arland standards. The inoculum's size was 1 $\times 10^{8} \mathrm{cells} / \mathrm{ml}$. The media Mueller Hinton Agar No. 2 and MRS media and the test bacterial cultures were poured into Petri dishes Hi-Media. The test strain $200 \mu \mathrm{l}$ was inoculated into the media inoculums size $10^{8}$ cells $/ \mathrm{ml}$ when the temperature reached $40^{\circ} \mathrm{C}-42^{\circ} \mathrm{C}$. The test compound $20 \mu \mathrm{l}$ was impregnated in to sterile discs 7 $\mathrm{mm}$ Hi-Media and was then allowed to dry. The disc was then introduced into medium with the bacteria. For each microbial strain negative controls were maintained where pure solvent DMSO was used instead of the extract since it does not possess any antimicrobial effect [22] and for positive control the standard antimicrobics Gentamicin $10 \mu \mathrm{g} / \mathrm{disc}$ and piperacillin $100 \mu \mathrm{g} / \mathrm{disc}$ for bacteria, nystatin 100 units/disc and flucanazole $10 \mu \mathrm{g} /$ disc Himedia Labs for fungus were used for comparative studies. The plates were incubated overnight at $37^{\circ} \mathrm{C}$ for bacterial strains and $42^{\circ} \mathrm{C}$ for fungal strains. The experiment was performed under strict aseptic conditions. Microbial growth was determined by measuring the diameter of the zone of inhibition. The experiment was performed in triplicates and the mean values of the result are shown in Tables 1-5.

\section{Results and Discussion}

Herbal medicine in developing countries is commonly used for the traditional treatment of health problems [23]. In recent years multiple drug resistance in human pathogenic microorganisms have developed due to the indiscriminate use of commercial antimicrobial drugs commonly used in the treatment of infectious diseases [24]. In addition to this problem, antibiotics are sometimes associated with adverse effects on host including hypersensitivity, immunosuppression and allergic reactions [25]. Therefore there is a need to develop alternative antimicrobial drugs for the treatment of infections obtained from various sources such as medicinal plants [26, 27].
In the present study $T$. catappa leaf extracts extracted in DMF (TDE), acetone (TAE) and methanol (TME) were investigated for their antimicrobial potentiality against 91 clinically important microbial strains. Drug resistance is a new problem, but it is not a new phenomenon. Soon after the introduction of penicillin, Staphylococci were found to be very resistant to many of the antibiotics. Although recognized earlier that antibiotics resistance was only in the hospitals, now resistance in the community is also seen. Bacteria such as Staphylococcus have emerged with resistance to six and more different antibiotics [28].

All the three extracts of T. catappa TDE, TAE and TME were active against $70 \%$ of the total Gram positive bacteria studied while only $63 \%$ of Gram negative bacteria were inhibited Tables 1-4, on the other hand, the three extracts of T. catappa were active against only $25 \%$ of fungal strains Table 5. The best antibacterial activity was shown by the methanol extract. Similar results were also shown by Babayi et al. [29] and Kaneria et al. [30]. The Gram positive bacteria were more susceptible than Gram negative bacteria. This is in agreement with previous reports that plant extracts are more active against Gram positive bacteria than Gram negative bacteria [31-33]. These differences may be attributed to the fact that the cell wall in Gram positive bacteria is of a single layer, whereas the Gram negative cell wall is multilayered structure [34].

The most striking feature of the present findings is that many of the clinical isolates were resistant to the standard antimicrobics used while the plant extracts showed moderate to good antibacterial activity. The need of the hour is to find new antimicrobics because the microorganisms are getting resistant to the existing antibiotics $[35,36]$. The persistent increase in multi drug resistant strains compels the search for more potent new antibiotics. Thus there is a need for a continuous search for new effective and affordable antimicrobial drugs. The results of present study signify the potentiality of $T$. catappa leaf as a source of therapeutic agents which may provide leads in the ongoing search for antimicrobial botanicals.

\section{Conclusions}

Present study showed that the T. catappa leaf extracts possessed significant in vitro antimicrobial property against 91 clinical isolate as well as identified strains. The methanol extract exhibited strongest inhibitory effect on bacteria as compared to standard antibiotics against the tested microorganisms. It is necessary to carry out a bioassay guided fractionation of the extract in a bid to isolate and identify the compounds responsible for the antimicrobial activity. An elucidation of the mechanisms 
of action of these extract must be followed by toxicity and in vivo tests to determine the therapeutic applicability of such compounds in combination therapy. These are subjects of on-going investigation in our research group.

\section{Acknowledgements}

Financial support to R. Nair from UGC (DSA project), New Delhi and supply of clinical isolates by Micro Care and Spandan Diagnostic Laboratories, Rajkot are gratefully acknowledged.

\section{References}

[1] G. M. Cragg and D. J. Newman, "Drugs from Nature: Past Achievements, Future Prospects," In: M. M. Iwu and J. C. Wootton, Eds., Ethnomedicine and Drug Discovery, Elsevier Science, Amsterdam, 2002, pp. 23-37.

[2] A. A. Allero and A. J. Afolayan, "Antimicrobial Activity of Solanum tomentosum," African Journal of Biotechnology, Vol. 5, 2006, pp. 369-372.

[3] M. R. F. De Lima, J. De Souza Luna, A. F. Dos Santos, M. C. C. De Andrade, A. E. G. Sant Ana, J. P. Genet, B. Marquez, L. Neuville and N. Moreau, "Antibacterial Activity of Some Brazilian Medicinal Plants," Journal of Ethnopharmacology, Vol. 105, No. 1-2, 2005, pp. 137147. doi:10.1016/j.jep.2005.10.026

[4] J. Parekh, N. Karathia and S. Chanda, "Screening of Some Traditionally Used Medicinal Plants for Potential Antibacterial Activity," Indian Journal of Pharmaceutical Science, Vol. 68, 2006, pp. 832-834. doi:10.4103/0250-474X.31031

[5] J. Parekh and S. Chanda, "Antibacterial and Phytochemical Studies on Twelve Species of Indian Medicinal Plants," African Journal of Biomedical Research, Vol. 10, 2007, pp. 175-181.

[6] M. H. S. Hediat and N. Marraiki, "Antimicrobial Activity and Phytochemical Analyses of Polygonum aviculare L. (Polygonaceae), Naturally Growing in Egypt," Saudi Journal of Biological Sciences, Vol. 17, No. 1, 2010, pp. 57-63. doi:10.1016/j.sjbs.2009.12.009

[7] S. Dash, L. K. Nath, S. Bhise and B. Nihar, "Antioxidant and Antimicrobial Activities of Heracleum nepalense D. Don Root," Tropical Journal of Pharmaceutical Research, Vol. 4, 2005, pp. 341-347.

[8] R. Nair and S. Chanda, "Antibacterial Activity of Some Medicinal Plants against Some Medically Important Bacterial Strains," Indian Journal of Pharmacology, Vol. 38, 2006, pp. 142-144. doi:10.4103/0253-7613.24625

[9] M. B. Tadhani and R. Subhash, "In vitro Antimicrobial Activity of Stevia rebaudiana Bertoni Leaves," Tropical Journal of Pharmaceutical Research, Vol. 5, 2006, pp. 557-560.

[10] S. Mandal, M. D. Mandal and N. Pal, "Antibacterial Potential of Azadirechta indica Seed and Bacopa monniera Leaf Extracts against Multidrug Resistant Salmonella en- terica Serovar Typhi Isolates," Archives of Medical Science, Vol. 3, 2007, pp. 14-18.

[11] R. Nair and S. Chanda, "In-vitro Antimicrobial Activity of Psidium guajava L. Leaf Extracts against Clinically Important Pathogenic Microbial Strains," Brazilian Journal of Microbiology, Vol. 38, 2007, pp. 452-458. doi:10.1590/S1517-83822007000300013

[12] S. Chanda, Y. Baravalia, M. Kaneria and K. Rakholiya, "Fruit and Vegetable Peels-Strong Natural Source of Antimicrobics," In: A. Mendez-Vilas, Ed., Current Research, Technology and Education Topics in Applied Microbiology and Microbial Biotechnology, Formatex Research Center, Spain, Vol. 2, 2010, pp. 444-450.

[13] S. Chanda, S. Dudhtra and M. Kaneria, "Antioxidative and Antimicrobial Effects of Seeds and Fruit Rind of Nutraceutical Plants Belonging to the Fabaceae Family," Food and Function, Vol. 1, 2010, pp. 308-315. doi:10.1039/c0fo00028k

[14] N. Y. Chiu and K. H. Chang, "The Illustrated Medicinal Plants of Taiwan," SMC Publishing, Inc., Taipei, Vol. 1, 1986, p. 129.

[15] C. C. Lin, Y. L. Chen, J. M. Lin and T. Ujiie, "Evaluation of the Antioxidant and Hepatoprotective Activity of Terminalia catappa," American Journal of Chinese Medicine, Vol. 25, 1997, pp. 153-161. doi:10.1142/S0192415X97000172

[16] A. N. Nagappa, P. A. Thakurdesai, N. V. Rao and J. Singh, "Antidiabetic Activity of Terminalia catappa Linn. Fruits," Journal of Ethnopharmacology, Vol. 88, No. 1, 2003, pp. 45-50. doi:10.1016/S0378-8741(03)00208-3

[17] Y. M. Fan, L. Z. Xu, J. Gao, Y. Wang, X. H. Tang, X. N. Zhao and Z. X. Zhang, "Phytochemical and Anti-Inflammatory Studies on Terminalia catappa," Fitoterapia, Vol. 75, No. 3-4, 2004, pp. 253-260. doi:10.1016/j.fitote.2003.11.007

[18] Y. F. Zhai, J. Yao, Y. M. Fan, L. Z. Xu, J. Gao and X. N. Zhao, "Inhibitory Effects of LR-98 on Proliferation of Hepatocarcinoma Cells," Journal of Nanjing University of Natural Science, Vol. 37, 2001, pp. 213-217.

[19] L. Z. Xu, J. Gao, L. Zhu, M. Xu, S. Y. Lu, X. N. Zhao and Z. X. Zhang, "Protective Effects of LR-98 on Hepatotoxicity Induced by Carbon Tetrachloride and D-Galactosamine in Mice," Journal of Nanjing University of $\mathrm{Na}$ tural Science, Vol. 36, 2000, pp. 197-201.

[20] A. W. Bauer, W. M. M. Kirby, J. C. Sherries and M. Truck, "Antibiotic Susceptibility Testing by a Standardized Single Disk Method," American Journal of Clinical Pathology, Vol. 45, 1966, pp. 426-493.

[21] J. Parekh and S. Chanda, "In vitro Antimicrobial Activity of Trapa natans L. Fruit Rind Extracted in Different Solvents," African Journal of Biotechnology, Vol. 6, 2007b, pp. 766-770.

[22] M. J. Pelczar, E. C. S. Chan and N. R. Krieg, "Microbiology Concepts and Applications," Mc Graw-Hill Inc, New York, 1993.

[23] M. J. Martinez, J. Betancourt, N. Alanso-Gonzalea and A. Jauregui, "Screening of Some Cuban Medicinal Plants for 
Antimicrobial Activity," Journal of Ethnopharmacology, Vol. 52, No. 3, 1996, pp. 171-174.

doi:10.1016/0378-8741(96)01405-5

[24] R. F. Service, “Antibiotics that Resist Resistance," Science, Vol. 270, 1995, pp. 724-727. doi:10.1126/science.270.5237.724

[25] S. Kilani-Jaziri, W. Bhouri, I. Skandrani, I. Limem, L. Chekir-Ghedira and K. Ghedira, "Phytochemical, Antimicrobial, Antioxidant and Antigenotoxic Potentials of Cyperus rotundus Extracts," South African Journal of Botany, Vol. 77, No. 3, 2011, pp. 767-776. doi:10.1016/j.sajb.2011.03.015

[26] D. Penduka, O. O. Okoh and A. I. Okoh, "In-vitro Antagonistic Characteristics of Crude Aqueous and Methanolic Extracts of Garcinia kola (Heckel) Seeds against Some Vibrio Bacteria," Molecules, Vol. 16, 2011, pp. 27542765. doi:10.3390/molecules 16042754

[27] M. K. Z. Yuen, R. W. K. Wong, U. Hagg and L. Samaranayake, "Antimicrobial Activity of Traditional Chinese Medicines on Common Oral Bacteria," Chinese Medicine, Vol. 2, 2011, pp. 37-42. doi: $10.4236 / \mathrm{cm} .2011 .22007$

[28] L. Stuart, "Infectious Diseases and Rise of Antibiotic Resistance," Pharmaceutical News, Vol. 3, 1996, p. 21.

[29] H. Babayi, I. Kolo, J. I. Okojun and U. J. J. Ijah, "The Antimicrobial Activities of Methanolic Extracts of Eucalyptus camaldulensis and Terminalia catappa against Some Pathogenic Microorganisms," Biokemistri, Vol. 16, 2004, pp. 106-111.

[30] M. Kaneria, Y. Baravalia, Y. Vaghasiya and S. Chanda, "Determination of Antibacterial and Antioxidant Potential of Some Medicinal Plants from Saurashtra Region,
India," Indian Journal of Pharmaceutical Sciences, Vol. 71, 2009, pp. 406-412. doi: $10.4103 / 0250-474 X .57289$

[31] J. E. Kelmanson, A. K. Jager and J. Van staden, "Zulu Medicinal Plants with Antimicrobial Activity," Journal of Ethnopharmacology, Vol. 69, No. 3, 2000, pp. 241-246. doi:10.1016/S0378-8741(99)00147-6

[32] J. Parekh and S. Chanda, "Screening of Some India Medicinal Plants for Antibacterial Activity," Indian Journal of Pharmaceutical Sciences, Vol. 68, 2006, pp. 835-838. doi:10.4103/0250-474X.31032

[33] V. P. Kumar, S. C. Neelam, H. Padh and M. Rajni, "Search for Antibacterial and Antifungal Agents from Selected Indian Medicinal Plants," Journal of Ethnopharmacology, Vol. 107, No. 2, 2006, pp. 182-188. doi:10.1016/j.jep.2006.03.013

[34] D. Djenane, J. Yangüela, L. Montanes, M. Djerbal and P. Roncales, "Antimicrobial Activity of Pistacia lentiscus and Satureja montana Essential Oils against Listeria monocytogenes CECT 935 Using Laboratory Media: Efficacy and Synergistic Potential in Minced Beef," Food Control, Vol. 22, 2011, pp. 1046-1053. doi:10.1016/j.foodcont.2010.12.015

[35] I. Bhattacharjee, A. Ghosh and G. Chandra, "Antimicrobial Activity of the Essential Oil of Cestrum diurnum L. Solanales: Solanaceae," African Journal of Biotechnology, Vol. 4, 2005, pp. 371-374.

[36] F. Scazzocchio, M. F. Cometa, L. Tomassina and M. Palmery, "Antimicrobial Activity of Hydrastis canadensis Extract and It's Major Isolated Alkaloids," Planta Medica, Vol. 67, 2001, pp. 561-563. doi:10.1055/s-2001-16493 